\title{
The Development Way of Forensic Accounting in China
}

\author{
Haiyan Sui ${ }^{1}$ \\ ${ }^{1}$ School of Finance and Economics, Shandong Jiaotong University, Jinan, China \\ Correspondence: Haiyan Sui, School of Finance and Economics, Shandong Jiaotong University, No.5001, Haitang \\ Road, Changqing University Science \& Technology Park, Jinan City, Shandong Province, China. Postcode: 250357. \\ Tel: 86-1861-541-6926. E-mail: suihy77@163.com
}

Received: July 19, 2013

Accepted: August 2, 2013

Online Published: August 5, 2013

doi:10.5430/afr.v2n3p119

URL: http://dx.doi.org/10.5430/afr.v2n3p119

\begin{abstract}
Forensic Accounting has been translated into Court Accounting, Litigation Accounting. It first appeared in the United States in the late 1870s and early 1880s, which mainly related to the US internal stock fraud case of domestic enterprise and the scandal of saving and credit industry. Since the end of the 20th century, forensic accounting grew rapidly in China affected by the prosperous of international forensic accounting. Despite a lot of research results of forensic accounting have been made by many scholars and experts, the application of forensic accounting is limited. This paper aims at studying the developing conditions and finding a developing way of forensic accounting in China.
\end{abstract}

Keywords: Judicature, Forensic accounting, Study on forensic accounting

\section{Introduction}

People are still unfamiliar with the term "forensic accounting" in our country, but it's another story if it is replaced by the word "judicial accounting". In 1954, some universities and colleges offer "accounting and judicial account verification" course as an elective course in law major according to the requirement of Higher Education Department of our country. Afterwards, Justice Department named this course as "judicial accounting" when formulating curriculum system for the law major. The scholars of several main politics and law universities and colleges began to study on the judicial accounting. In 1985, the procuratorial organ started manning judicial account verification and launched the construction of Chinese judicial accounting industry which in turn affected the academia.

Since the end of the 20th century, forensic accounting grew rapidly in China affected by the prosperous of international forensic accounting. Numerous scholars and experts swarm into this field and give their fruitful research results. The amount of the articles published only on publications was nearly 200 after the first famous scholars published the article about forensic accounting which doesn't include relevant academic conference, dissertations and books. The theoretical research on forensic accounting has seen dramatic breakthroughs.

I think forensic accounting and judicial accounting is not completely independent of each other because forensic accounting emerged by the need of judicial practice and forensic accounting is the product of the development of economy and society.

\section{Current situation}

\subsection{Main research fields of forensic accounting}

The hot research on forensic accounting in China make Chinese academia is on the contention of a hundred schools of thought. The current research is mainly focused on the following four aspects. One aspect is about the research on the theory framework of forensic accounting, such as "Study on Forensic Accounting Theory" (e.g., Yao, 2006), "The Conception of Basic Theoretical Framework of Forensic Accounting with Chinese Characteristics" (e.g., Dong, 2006), "Brief Analysis on the Theoretical Framework of Forensic Accounting of Our Country" (e.g., Liu, 2006), etc. One aspect is related to the education on forensic accounting and personnel training, such as "Elementary Discussion on Forensic Accounting Personnel Training in Colleges and Universities of Our country"(e.g., Liu, 2008), etc. One aspect is to differentiate forensic accounting from similar disciplines, such as "Different Law Systems, but the Same Essence-Understanding of Judicial Accounting and Forensic Accounting" (e.g., Zhao, 2010), "A Comparative Study of Forensic Accounting and Auditing"(e.g., Li, 2010), etc. Another aspect is focused on the applications analysis of forensic accounting, such as "The Role of Forensic Accounting on Examining and Verifying Financial Fraud of Listed Companies”(e.g., Liu, 2010), etc. 


\subsection{Current application situation}

Our country's current forensic accounting cannot meet the need of judicial practice, especially in the protection of the rights and interests of investors and maintaining the healthy development of the securities market. Forensic accounting does not play a good role.

One researcher, Ying Zhang, made a social investigation mainly for professionals from the August of 2005 to the February of 2006 which is named as "Chinese Forensic Accounting and its Development Situation Investigation". The survey data reflected that the promotion strength of forensic accounting in China is insufficient and the social awareness is low because many professionals even don't know what forensic accounting is. That showed that the reality application range of forensic accounting in our country was narrow and its social influence was not significant. The investigation also announced that those who were active in the fields of economy and in participating the economic disputes settlement were attorneys and CPAs, the earliest professionals in contact with forensic accounting. This reflected our judicial department and accounting firms had been carried out in a certain proportion of forensic accounting business, but only in a few aspects. Affected by the theoretical study of forensic accounting in China, the application of it was confined in judicial accounting and a few other small branches. Forensic Accounting was most widely used in judicial aspects. In economic cases, justice division made investigation and collected evidence to provide expert support for legal proceedings. This is the most original piece of forensic accounting. Litigation accounting is also the first application of forensic accounting according to foreign experience.

In the August of 2006, International FCPA (Forensic Certified Public Accountant) Professional Certification Center, International Forensic Accounting Network Cooperated with China University of Political Science and Law and Renmin University of China to organize the first forensic accounting seminar. In the meantime, International FCPA Professional Certification Center began to develop the training, examination and certification business of relevant qualification certificate. This makes the practice of forensic accounting in China have a groundbreaking development and the forensic accounting started to take root in our country indeed.

\section{Development conditions}

\subsection{Demand of market economy}

Under the planned economy system, national unified arrangement on demand and all of the goods were unified arrangement by the nation and could not be freely traded, so the economic activity was simple and single. In countries with strict control, forensic accounting was not necessary. But as the development of market economy, the economic activities both in content and in form of expression are more perplexing. Economic business becomes more and more, due to different economic interest relationship in economic interaction, the economic cases caused by frictions also can hardly be avoided. The demand for forensic accounting also increased. Now regulating the economic activity in all acts by the law has become the characteristics of all the countries with market economic system. The lawsuit is an effective means for each economy main body to protect their own rights and interests. While almost all economic activities are related to accounting. Therefore, forensic accounting is facing more and more market demand along with the development of our market economy and the improvement of law environment.

\subsection{Weakness of accounting integrity}

Accounting information reflects a company's operating results truly and fairly under certain guidelines. It provides the necessary true reference data for the information users, which is the basis of investment decisions. However, in recent years, a number of financial scandals occurred. For example, Enron made a false report about its profits of $\$ 600000000$, Xerox misrepresented its sales revenue of $\$ 6400000000$, Merck made a false report about its triennial total revenue of $\$ 12.4$ billion. Those not only make the users of accounting information lose confidence in the authenticity of accounting information, but also greatly reduce the corporate accounting integrity. The accounting integrity of the enterprises of our country is even lower. The financial scandals of our country happened a lot and even some CPA firms are involved in them. The public also generated suspicion on CPA integrity. Therefore, it requires some new professionals to control and strike these fraud actions to ensure the fairness and truth of the accounting information. The new professionals are the forensic accounting professionals.

\subsection{Need of judicial practice}

In many fraud cases of Chinese listed companies, the court could not identify the responsibility of the false financial statements and determine the economic loss of the investors due to the lack of a specific interpretation of the law. Therefore the court had to dismiss the investor's litigation because of no direct causal relationship. This brought very tremendous attack to the investors and significant influenced the investment environment in China. Similarly, in many of domestic and foreign accounting fraud cases, the legal responsibility caused by the accounting information 
distortion also reflects the contradiction between the accounting regulation and the law. To coordinate or eliminate it, the professionals who are the mastery of legal and accounting are needed to make professional identification on the accounting information or related events from the accounting professional and legal integration perspective in order to make the reflection of accounting behaviors and the legal consequence in judicial practice be generally consistent to realize accounting legalization.

\subsection{Rapid development of insurance business in China'}

During the 5 years from 2006 to 2010, Chinese insurance industry has made remarkable achievements. The number of insurance company moved from 93 to 146 and the premium income increased from 492700000000 Yuan of the end of "the Tenth Five-Year Plan" period to 1452700000000 Yuan of 2010 year end which had an increase of 1.95 times. Furthermore, the total assets of the entire industry increased from 1552500000000 Yuan of the end of "the Tenth Five-Year Plan" period to 5048100000000 Yuan of 2010 year end which grew 2.25 times. Because Chinese insurance industry is still in the rapid development period and the employing mechanisms of insurance companies are very flexible, some salesman inevitably operated illegally, or even mislead customers which increases the occurrence probability of disputes. While the general public doesn't understand thoroughly the relevant clauses in insurance contract and are not very clear about whether they can claim to such issues, their interests are vulnerable. So it requires forensic accounting professionals to make professional identification to provide expert advice for disputing.

\section{Countermeasures}

\subsection{Improving the legal environment related to forensic accounting}

At present, there are still many gaps in the accounting laws, for instance, some economic laws and regulations such as Evidence Act, Investment Act and Property Law need extremely to be regulated. It's still necessary to modify and perfect Accounting Law, Auditing Law, Statistics Law, Tax Law, Law on Certified Public Accountants etc. Fortunately, the newly revised Company Law and Securities Law duly augmented the provisions of law enforcement and regulatory. For example, it strengthens the supervisory power and law enforcement means of the securities regulatory authority under the State Council in Securities Law, particularly the coercive power to carry out inspection and investigation on illegal behavior. It is a good news for the forensic accounting industry because it further standardized our country economic environment and legal environment which is conducive to the development of forensic accounting.

\subsection{Setting up Forensic Accounting Committee}

As a forensic accounting management mechanism, Forensic Accounting Committee should promptly develop, organize, manage and coordinate the development of forensic accounting, personnel training and certification. There are many forensic accounting organizations and institutions active in related fields around the world, which play a decisive role in promoting the development of forensic accounting, such as Forensic and Litigation Services Committee (FLS Committee) under the American Institute of Certified Public Accountants etc. Drawing a lesson from foreign practices, we can establish Forensic Accounting Committee under the Chinese Institute of Certified Public Accountants which accepts its management. The Forensic Accounting Committee should be responsible for the council of the Chinese Institute of Certified Public Accountants and dedicate to the management, instruction and supervision of the forensic accounting business. The forensic accountants also must comply with Chinese Certified Public Accountants Practice Standard.

\subsection{Establishing the certification mechanism of forensic accounting}

The current supply and demand gap is bigger in China and the corresponding training mechanism has not been started. We must firstly establish forensic accounting qualification certification system for the standardized development of forensic accounting which is a guarantee of quality and professional competence of forensic accounting team. Professionals obtain the qualifications of forensic accountants through participation in the qualification examination. Those who are fraud auditing professionals may be appropriate to relax the examination standards in order to relieve short-term pressure on the shortage of forensic accountants in China. we also should gradually develop higher education on forensic accounting in colleges and universities and designated some of them to construct forensic accounting discipline in order to train a large scale of forensic accountants of our country.

\subsection{Formulating forensic accounting practice standards}

As a kind of independent occupation, we should set up a set of accepted practice standards for forensic accounting to make the professionals distinguish the responsibilities of the parties based on evidences and rules. So it can avoid 
that both sides are justified and promote the healthy development of the forensic accounting industry. I suggest the standards of forensic accounting are set in China's independent auditing standards system and establish forensic accounting standards system in the form of practice advisories and practice guidelines.

\subsection{Developing together with accounting firms}

Learn from the development of Forensic Accounting Forensic in western countries, the forensic accounting business should be undertaken by the independent CPAs. There are $1 / 3$ of the accounting firms provide forensic accounting services in Canada. Lawyers, police, prosecutors, courts, insurance companies, banks, commercial groups often invite senior CPAs to provide forensic accounting services. Reported by the "Accounting Today" of American, $60 \%$ of the top 100 largest accounting firms developed forensic accounting services.

In our country, the CPAs have become the indispensable core force of the market economy system after more than 20 years of reform and development. With the accomplishment of the rectifying and restructuring it, the CPA industry of China stepped in the standardized and large-scale way. All the forensic accounting business will certainly be turned over to the CPAs from a long-term perspective which would also greatly broaden the business scope of the accounting firms and provide a more extensive development space for them.

\section{Conclusion}

With the development of market economy, the weakening of accounting integrity, the development of judicial practice and the insurance claim business, the demand for forensic accounting will increase. Consequently, breaking the bottleneck of the development and working together with public accounting firms is the development way of forensic accounting in China.

\section{References}

Dianjun Zhang \& Kai Zhang. (2010). Forensic accounting: Legal thinking and system construction. Finance and Accounting Monthly. 9, 6-9.

Fujian TV Station. (2011). China's Insurance Industry Developing Rapidly During the Eleventh Five-Year Plan. [Online] Available: http://finance.v1.cn/gn/2011-2-12/1297499940664_2.shtml

Shurong Yan \& Xi Kuang. (2008). Discussion on the present development of forensic accounting in our country. Friends of Accounting. 11, 13-14. http://dx.doi.org/10.3969/j.issn.1004-5937.2008.32.005

Wenya You \& Yuehong Lu. (2006). Discuss the development of forensic accounting in China. Finance and Accounting Monthly (Academic Edition). 6,17. http://dx.doi.org/10.3969/j.issn.1004-0994-B.2006.06.008

Xiaoyu Lang. (2006). Necessity of Developing Forensic Accounting. Liaoning Economy. 2, 95. http://dx.doi.org/10.3969/j.issn.1003-4617.2006.02.064

Xingwen Wu. Forensic accounting: Opportunities and challenges facing the accounting firm. Hunan Social Sciences. 2006;6:78-79. http://dx.doi.org/10.3969/j.issn.1009-5675.2006.06.021

Ying Zhang. (2006). Developing and Expanding Forensic Accounting Business in China. Auditing and Finance. 8, 36.

Zhao Yu. (2008). "Forensic Accounting” Reflecting the Coxcombical Phenomena of Chinese Social Sciences Academic. [Online] Available: http://www.studa.net/sifazhidu/080303/14455143.html 